\title{
The Narrative Structure and Ideational Meaning of Malay Short Stories
}

\author{
Siti Norashikin Azmi, Hanita Hassan, Wan Farah Wani Wan Fakhruddi
}

\begin{abstract}
Short stories are structured in a way to engage readers to the stories being told. This paper discusses the compatibility between Narrative Structure of Malay Short Stories and Labov and Waletzky's (1967) Narrative Structure of Casual Conversation. The narrative analysis was conducted on the literary works of a prominent Malaysian Female Writer, Zurinah Hassan entitled "Catatan di Meja Makan" (Notes at the Dining Table), "Anita" and "Perjalanan Sendiri" (Own Journey). The findings suggest that the narrative structure of Malay Short Stories has the same stages as outlined by Labov and Waletzky's, and the stages are Orientation, Complication, Evaluation, Resolution and Coda. Following that, the Orientation stage was further analysed using Transitivity analysis as introduced by Halliday's SFL (1994). The analysis shows that the most frequent process found in the Malay short stories is Action Process with 63 occurrences and followed by Mental Process with 24 occurrences. These two process types connote the active actions of the characters of the short stories either physically or mentally. In relation to the process types, participant types of Action process which are Actor and Goal have the highest occurrences, 46 and 44 respectively, whilst participant types of Mental process, Senser and Phenomenon with 20 and 17 occurrences. The findings suggest that the main aim of Orientation stage in Malay short stories is to foreground the characters, as doers and sensers, and and highlight their physical and mental activities.
\end{abstract}

Keywords: ideational metafunction, narrative structure, Malay Short Stories, systemic functional linguistics, transitivity analysis.

\section{INTRODUCTION}

Short story is an invented prose narrative which is shorter than a novel. It deals with few characters and concentrates on creation of mood rather than plot. Since short stories are considered as part of a narrative genre, the aim is to engage readers or listeners towards the story being told. In order to attract the readers' attention, writers structured the story into several elements or stages as a means of assisting readers to understand the flow of the story. And it is important to note that the Orientation stage is the stage by which readers will decide either the story is worth reading or not.

In 1967, [1] introduced six elements of Narrative Structure, which are Abstract, Orientation, Complication, Evaluation, Resolution, and Coda. Even though the elements were outlined from casual conversation, studies have shown that the elements are also found in written literature $[2,3]$. The function of each element is different from one to another, of

Revised Version Manuscript Received on April 19, 2019.

Siti Norashikin Azmi, Language Academy, Faculty of Social Sciences and Humanities, Universiti Teknologi Malaysia, Johor, Malaysia.

Hanita Hassan, Language Academy, Faculty of Social Sciences and Humanities, Universiti Teknologi Malaysia, Johor, Malaysia.

Wan Farah Wani Wan Fakhruddin, Language Academy, Faculty of Social Sciences and Humanities, Universiti Teknologi Malaysia, Johor, Malaysia. which Orientation introduces the story by highlighting who the character is, when, where and how it happens; Complication tells the events of the story; Evaluation connotes how and why the story is interesting; Resolution tells the ending of the story; and lastly, Coda is to bring back readers to the present. In addition, Transitivity analysis was also conducted on the Orientation stage to examine the realisation process of meaning-making.

Systemic Functional Linguistics has been applied to interpret online debate texts [4], short stories [5], and parables [6]. [4] examined the meaning of online debate using ideational metafunction and focusing on the field, tenor and mood. The finding suggests that in communicating, speaker's choice of text and language system depends heavily on the target group, for example,who are the users/audiences. In addition, [5] conducted interpersonal and textual analyses on two short stories entitled the Romantic Movement and the Gothic. According to [7], interpersonal metafunction deals with the way a writer tries to relate to the readers. $\mathrm{He}$ found that the writers of both short stories used a monologue style of narration to closely relate readers into their stories. Textual metafunction, on the other hand, deals with 'what information is taken as given' [7]. Both stories used dialogic mode that focus on the first person as narrator that initiates the type of action, who responds to that action and how [7].

Systemic Functional Linguistics (SFL) has been used in Malay literary studies. SFL was used to study Sumatran folktales [8] and a Malay novel [9]. [8] studied three Sumatran folktales entitled Batu Belah Batu Bertangkup, Putri Kuau, and Sri Putih Cermin and found that all of them shared the same structure, function and meaning. It is stated that the most frequent process found was material process $(53.12 \%)$ and followed by verbal process. [9], on the other hand, examined the applicability of Halliday's process types to Malay text. The findings of his study are reflected heavily on the process types of Halliday [10], but with labels which suit Malay texts and the Malay process types will be further explained in the following section.

\section{METHODOLOGY}

The data for this study were taken from the short stories by Zurinah Hassan entitled "Catatan di Meja Makan" (later is referred as Short Story 1 or ST1), "Anita" (later is referred as Short Story 2 or ST2) and "Perjalanan Sendiri" (later is referred as Short Story 3 or ST3). This study adopted the Narrative Structure as outlined by [1] which consists of 5 
International Conference on Recents Advancements in Engineering and Technology (ICRAET-18) |15th and 16th March 2019|Siddhartha Institute of Technology \& Sciences, Telangana, India.

stages. The stages or elements are Orientation, Complication, Evaluation, Resolution and Coda. The stage and its description are outlined in Table 1.

Table 1: The Stages of Narrative Structure by [1]

\begin{tabular}{|l|l|}
\hline Type of Stages & Description \\
\hline Orientation & $\begin{array}{l}\text { Details of People involved, time, place, } \\
\text { and situation of the narration. }\end{array}$ \\
\hline Complication & $\begin{array}{l}\text { Series of Complicated events/ problem/ } \\
\text { conflict faced by people }\end{array}$ \\
\hline Evaluation & $\begin{array}{l}\text { Revelation of attitude of people towards } \\
\text { the problematic events in Complication } \\
\text { stage. }\end{array}$ \\
\hline Resolution & Define the result of the narration. \\
\hline Coda & $\begin{array}{l}\text { Bringing the narration to the beginning of } \\
\text { the story }\end{array}$ \\
\hline
\end{tabular}

After identifying the five stages of Malay short stories, the Orientation stage of Malay short stories was then analysed from the ideational metafunction perspective. This is to say that the meaning-making process was examined using Transitivity analysis $(10 ; 9]$. This analysis helped determine the most prominent process and participant types in the Orientation stage of Malay short stories. The descriptions of Malay Process types and participants are shown in Table 2.

Table 2: Process Types and Participants found in Malay Texts.

\begin{tabular}{|c|c|c|}
\hline Process type & \multicolumn{2}{|l|}{ Participant } \\
\hline \multirow{5}{*}{$\begin{array}{l}\text { Action (Lakuan) } \\
\text { Function: Represents } \\
\text { physical action (including } \\
\text { metaphors) }\end{array}$} & Actor & $\begin{array}{l}\text { One who does } \\
\text { the action }\end{array}$ \\
\hline & Goal & $\begin{array}{l}\text { One who is } \\
\text { affected by the } \\
\text { action }\end{array}$ \\
\hline & Range & $\begin{array}{l}\text { Domain } \\
\text { where process } \\
\text { takes place }\end{array}$ \\
\hline & Recipient & $\begin{array}{l}\text { One who } \\
\text { receives } \\
\text { something } \\
\end{array}$ \\
\hline & Beneficiary & $\begin{array}{l}\text { One for whom } \\
\text { something is } \\
\text { done }\end{array}$ \\
\hline \multirow[t]{2}{*}{$\begin{array}{l}\text { Mental (Minda) } \\
\text { Function: Process of } \\
\text { sensing }\end{array}$} & Senser & $\begin{array}{l}\text { Person who } \\
\text { experiences } \\
\text { and reacts } \\
\text { mentally in } \\
\text { the process. } \\
\text { Can occur } \\
\text { without a } \\
\text { presence of a } \\
\text { Phenomenon. }\end{array}$ \\
\hline & Phenomenon & $\begin{array}{l}\text { Entity being } \\
\text { perceived, } \\
\text { thought, } \\
\text { appreciated, } \\
\text { etc. }\end{array}$ \\
\hline \multirow[t]{3}{*}{$\begin{array}{l}\text { Verbal (Verbal) } \\
\text { Function: Process of } \\
\text { speaking or utterance }\end{array}$} & Speaker & $\begin{array}{l}\text { Person who } \\
\text { communicates } \\
\text { trough speech } \\
\end{array}$ \\
\hline & Listener & $\begin{array}{l}\text { One receiving } \\
\text { the utterance }\end{array}$ \\
\hline & Target & $\begin{array}{l}\text { Person the } \\
\text { speech is }\end{array}$ \\
\hline
\end{tabular}

[10] has outlined eight process types namely Material, Mental, Relational, Attributive, Identifying, Behavioral, Verbal, and Existential. Following the process types outlined by [10], [9] analyzed the process and participant types in a Malay novel. He outlined six process types and its respective participant types of Malay literature. The process types are Action, Mental, Identifying, Existential, Relational and Descriptive. Participant types for Action process are Actor, Goal, Range, Recipient, and Beneficiary; whilst for Mental process types are Senser and Phenomenon; for Verbal process are Speaker, Listener, Target and Verbiage; and the participant for Situation process is Experiencer. Participant types for Description process are Introducer and Value; while participants for Existence process are Introducer and Existent; and Relational process are Identifier, Identity, Carrier and Attribute. The transitivity analysis done in this study used the process types and participants as listed by [9].

\section{FINDINGS}

The findings of narrative analysis done on Malay short stories conclude that the Narrative structure by [1] is applicable towards Malay Short Stories. For a Narration to be able to engage readers towards the text, writers unfold the story into several stages namely Orientation, Complication, Evaluation, Resolution and Coda. Given the fact that Orientation stage comes at the beginning of the structure, this 
stage is therefore regarded as the most important stage and it must be appealing to the readers to continue reading. This can be clearly seen as words in this stage were carefully selected to trigger what will come in the next stages. While moving towards the next stages, information on people involved, place, time and initial situation was given. The Orientation stage is followed by Complication Stage and the function of this stage is to provide circles of Complicating events in the narrative. The narrative then continues with Evaluation stage, in which the events are evaluated. The next stage is Resolution which illustrates the result of the whole story before Coda stage brings the readers back to the earlier stage of the story. Table 3 illustrates the compulsory stages which were found in all Malay Short Stories and the stages are Orientation, Complication, Evaluation and Resolution [11]. However, Coda is regarded as an optional stage, since it could only be found in short stories 1 and 3 ; in other words, it is

Table 3: Stages of the Narrative Structure of Malay Short Stories

\begin{tabular}{|l|l|c|c|c|}
\hline \multicolumn{2}{|l|}{$\begin{array}{l}\text { Structure of Malay } \\
\text { Short Stories }\end{array}$} & $\begin{array}{c}\text { Short } \\
\text { Story 1 }\end{array}$ & $\begin{array}{c}\text { Short } \\
\text { Story 2 }\end{array}$ & $\begin{array}{c}\text { Short } \\
\text { Story 3 }\end{array}$ \\
\hline \multirow{4}{*}{ Orientation } & People & $\sqrt{ }$ & $\sqrt{ }$ & $\sqrt{ }$ \\
\cline { 2 - 5 } & Time & $\sqrt{ }$ & $\sqrt{ }$ & $\sqrt{ }$ \\
\cline { 2 - 5 } & Place & $\sqrt{ }$ & $\sqrt{ }$ & $\sqrt{ }$ \\
\cline { 2 - 5 } & Situation & $\sqrt{ }$ & $\sqrt{ }$ & $\sqrt{ }$ \\
\hline Complication & $\sqrt{ }$ & $\sqrt{ }$ & $\sqrt{ }$ \\
\hline Evaluation & $\sqrt{ }$ & $\sqrt{ }$ & $\sqrt{ }$ \\
\hline Resolution & $\sqrt{ }$ & $\sqrt{ }$ & $\sqrt{ }$ \\
\hline Coda & $\sqrt{ }$ & & $\sqrt{ }$ \\
\hline
\end{tabular}

(Note: $\sqrt{ }$ indicate that the element/stage is found in the Short Stories)

After the identification of narrative stages of Malay Short Story, the ideational meaning of Orientation stage was then examined using Transitivity analysis. The findings of the analysis suggest that in Malay short stories, Action process is prominent with $49.6 \%$ occurrences. This is parallel with the findings of [8], of which the most frequent process types found in Sumatran Malay folktales is Action process. As Action process aims to illustrate physical action, writers use action process types to indicate the characters' activities. However, the second frequently process type found in the Sumatran Malay folktales is Verbal process type, unlike Malay short stories, of which mental process type with $18.9 \%$ occurrences is the second most frequently found compared to $13.4 \%$ of Verbal Process. Mental action suggests that the participant is still doing an action but in a form of mental action [10]. This thus suggests that the orientation stage of Malay short stories highly foregrounds the characters' physical and mental activities. It is interesting to note that the Verbal process $(13.4 \%)$ is the third frequently process type found but this process type was only found in ST3. In comparison, even though the occurrence of Situational Process is less then Verbal process, which is $7.1 \%$, the Situational process types were found in all Short Stories $(7.1 \%)$. Other process types found in Malay Short stories are insignificant, for example, Relational (5.5\%), Existence (3.9\%), and Description (1.6\%). These process types illustrate relationship, explanation, entity and setting of the missing in short story 2 .

characters in Malay short stories (see Table 4).

Table 4: The Distribution of Process Types found in Malay Short Stories.

\begin{tabular}{|l|c|c|c|c|c|}
\hline $\begin{array}{l}\text { Process } \\
\text { Types }\end{array}$ & ST1 & ST2 & ST3 & Frequency & $\begin{array}{c}\text { Percentag } \\
\text { e (\%) }\end{array}$ \\
\hline Action & 17 & 13 & 33 & 63 & 49.6 \\
\hline Mental & 12 & 9 & 3 & 24 & 18.9 \\
\hline Verbal & - & - & 17 & 17 & 13.4 \\
\hline Situation & 3 & 5 & 1 & 9 & 7.1 \\
\hline Relational & - & 3 & 4 & 7 & 5.5 \\
\hline Existence & 1 & 4 & - & 5 & 3.9 \\
\hline Description & 2 & - & - & 2 & 1.6 \\
\hline Total & 35 & 34 & 58 & 127 & 100 \\
\hline
\end{tabular}

(Note: ST indicate the Malay Short Stories)

As shown in Table 4, Action process is the most prominent process type and followed by Mental process. In conjunction to this, the most frequent Participant types found are those related to Action and Mental Pprocess types. Table 5 illustrates the Action process and its Participants found in the Malay short stories.

Table 5: Action Process and its Participants. Jadi dapatlah dia menyelesaikan tugas-tugas hariannya

\begin{tabular}{|c|c|c|}
\hline Clause & Jadi dapatlah & dia \\
\hline Analysis & $\begin{array}{l}\text { Circumstane: } \\
\text { Contingency } \\
\text { (Condition) }\end{array}$ & Participant: Actor \\
\hline & So able & she \\
\hline menyelesaikan & \multicolumn{2}{c|}{ tugas-tugas hariannya } \\
\hline \multicolumn{2}{|c|}{ Process: Action } & \multicolumn{2}{c|}{ her daily chores } \\
\hline \multicolumn{2}{|c|}{ settle }
\end{tabular}

Table 5 shows an Action process which is 'menyelesaikan' (settle) that was done by an Actor or 'dia' (she), and the Goal is 'tugas-tugas hariannya' (her daily chores). This clause has a Circumstantial element that is Condition, which acts as a description or an explanation at the beginning of the clause.

The examples of Mental Process and its Participants are shown in Table 6.

Table 6: Mental Process and its Participants.

Sudah beberapa hari dia berniat untuk menyusun laci almari rendah dekat meja itu

\begin{tabular}{|l|l|l|l|}
\hline Clause & $\begin{array}{l}\text { Sudah beberapa } \\
\text { hari }\end{array}$ & dia & berniat \\
\hline Analysis & $\begin{array}{l}\text { Circumstance: } \\
\text { Extent (Temporal) }\end{array}$ & $\begin{array}{l}\text { Participant: } \\
\text { Senser }\end{array}$ & $\begin{array}{l}\text { Process: } \\
\text { Mental }\end{array}$ \\
\hline & It has been few days & she & wish \\
\hline \multicolumn{2}{|l|}{ untuk menyusun laci almari rendah dekat meja itu. }
\end{tabular}

Circumstance: Location (Spatial)

To arrange the drawer of small cupboard near the table.

Table 6 shows a Mental Process type, 'berniat'(wish) and its participant, Senser ('dia' - she) with the accompaniment of Circumstantial elements of Extent and Location.

As mentioned previously, the extensive use of Action and Mental process types in the Orientation stage thus signifies the function of Orientation Stage in Malay Short stories is to foreground the physical and mental activities of the main characters. 
This is hence the means of attracting readers to read further, of which the aim is to know what will happen next.

\section{CONCLUSION}

This study only examined the Ideational Meaning of the Orientation Stage of Malay short stories. It is suggested that for future studies to focus on other stages of Narrative structure, for example, Complication, Evaluation, Resolution and Coda. It is also recommended for future researchers to analyse Malay Short Stories from other SFL metafunctions, namely Textual and Interpersonal, as a way of fully examining the realisation process of meaning-making in Malay Literary works.

\section{REFERENCES}

1. W. Labov, \& J. Waletzky, (1967). Narrative Analysis: Oral Version of Personal Experience. (H. J., Ed.) Essay on the Verbal and Visual Arts, 12-44.

2. M. Boyno, E. Akil, and F. Dolas. (2013). The Application of the Labovian Narrative Analysis to a Short Story in an EFL Class. Dumlupınar Üniversitesi Sosyal Bilimler Dergisi, vol. 37, pp. 113-122.

3. U. Khalil, (2017). Applying Labov's Narrative Structure to 'My Mom had only one Eye': Effective Narrative. The Discourse. Vol. 3, no. 1,

4. L. Wattles, \& B. Radis-Bojanic, (2007). The Analysis of an Online Debate - The Systemic Functional Grammar Approach. Linguistics and Literature, 5(1), 47-58.

5. F. Simsek, (2012). A multigroup multitrait-multimethod study in two countries supports the validityof a two-factor higher order model of personality. Journal of Research in Personality, 46. 442-449.

6. P. L. Graber, (2001). Context in Text" A Systemic Functional Analysis of the Parable of Sower. Atlanta: Emory University.

7. S. Eggins, (1994/2000). An Introduction to Systemic Functional Linguistics. London: Pinter Publishers.

8. T. T. Zein, (2015). North Sumatran Malay Folktales: Its Structure, Social Function and Meaning. Malay Literature, 167-199.

9. Idris Aman. (2014). Jurnal Bahasa. Retrieved May 15, 2015, from Dewan Bahasa dan Pustaka. [Online]. Available::

http://jurnalbahasa.dbp.my/wordpress/wp-content/upl oads/2014/08/1-Proses-dalam-ayat-wacana.pdf

10. M. A. Halliday, (1994). An Introduction to Functional Grammar. London: Edward Arnold.

11. S. Eggins, \& D. Slade, (1997). Analysing Casual Conversation. London: Equinox.

\section{AUTHOR'S PROFILES}

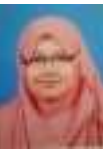

Siti Norashikin binti Azmi is a Master of Philosophy at Language Academy of Faculty of Social Sciences and Humanities. She has presented papers at several conferences in UTM

Associate Professor Dr Hanita Hassan is a lecturer at Language Academy, Faculty of Social Sciences and Humanities. She is currently the Chair of Language Academy and Head of Research Group (RG) of Language and Communication in Society. She has 30 years of experience in teaching undergraduate and postgraduate programmes and her research interests include Systemic Functional Linguistics (SFL), multimodality, discourse analysis and ELT methodology. Her book on Multimodal Communication of Corporate Website Design won the Original Book Award, UTM in 2012 and she is an editor for LSP International Journal. On top of that, she has presented papers at several international conferences as part of her academic activities, and her paper entitled The Roles of Media in Realising 'Unity in Diversity' presented at International Conference on Knowledge, Culture and Society 2012 in Jeju Island, South Korea, won the Best Paper Award.

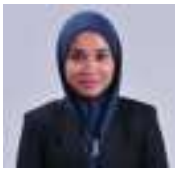

Dr Wan Farah Wani Wan Fakhruddin is a lecturer at Language Academy, Universiti Teknologi Malaysia. She did her $\mathrm{PhD}$ on Genre Analysis of Forestry Reports from a Systemic Functional Perspective 